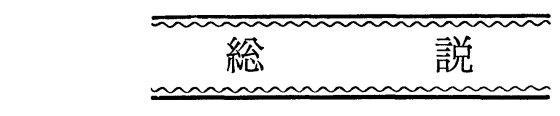

プラズマを用いた薄膜形成技術

神崎愷*，松本修*

\title{
Plasma Processing Technologies for Thin Film Formation
}

Yasushi KANZAKI*, and Osamu MATSUMOTO*

\section{1. は じめに}

Plasma $=$ Physics というイメージが長い間我々を支配 し，プラズマと言えば「難解」を意味した。しかし近年 半導体産業に和いてウェットプロセスに代るドライプロ セスの手段としてプラズマが登場しプラズマが我々にと って急速に親しみ易いものになってきたことはプラズマ 化学に携わる我々化学屋にとってられしい限りである。 プラズマとは簡単に言えば「気体がイオンと電子に解離 している状態」と定義することができ, 電気化学的には 液体電解質, 固体電解質と並ぶ「気体電解質」と見なす ことができる。一方熱的にプラズマ状態を作るためには $10^{4 \circ} \mathrm{C}$ 以上の温度が必要であり, 温度の順では固体, 液 体，気体の次に位置するので「第四の状態」と呼ばれる こともある。しかしこのような高温をそのまま取り扱う ことは工学的にははなはだ非現実的であり，プラズマ化 学がこれまであまり注目されなかった点もまさにここに ある。一方螢光灯やネオンサインで代表されるようにプ ラズマは非常に身近なものでもある。それは「放電」に よってだれにです簡単にプラズマを作ることができ気体 を低圧状態にすれば手で触れるような低温で高温（高エ ネルギー）状態が作れることを意味している。半導体産 業でプラズマプロセスが急速に普及したのもこの「低温 プラズマ」の特徵を利用したからに他ならない。薄膜形 成に就けプラズマプロセスのほとんどはこの低温プラ ズマに関連したものであるが，本稿では薄膜を広くとら えプラズマについては熱プラズマから低温プラズマま で，放電形成についても種々のものを取り上げ，薄膜に とらわれずより一般的な表面処理技術としてプラズマが どのように利用されているのかを述べてみたい。

* 青山学院大学理工学部化学科（干157 東京都世田谷 区千歳台6-16-1)

Dep. of Chem., College of Sci. and Engin., Aoyama Gakuin University (16-1, Chitosedai 6-chome, Setagaya-ku, Tokyo 157)

\section{2. プラズマ化学反応の特徵}

プラズマの関与する化学反応の特徵を示すためにまず 通常の化学反応（熱化学反応）と光化学反応との比較を してみよう。熱化学反応は Eyring の絶対反応速度論で 代表されるように反応は活性化状態を経て進むと考えら れる。このとき原系と活性化状態とは熱力学的に平衡に あると近似され, 活性化状態の数は Boltzmann 分布に 従うので反応速度は Arrhenius の式に従って温度の上 昇とともに指数関数的に増大する。光化学反応の主要素 である励起状態やラジカル, プラズマ化学反応の主要素 であるイオンの十分な量を熱化学的に作るには数万度の 温度が必要となる。一方光化学反応やプラズマ化学反応 の特徴の第一は反応の原系が熱力学的に安定な状態にな い励起種やイオンであることである。図 1 にこの様子を 模式的に示す。これらの反応では反応式に光エネルギー や,イオンの場合は電場のエネルギー（数〜数十 $\mathrm{eV}$, 温 度に換算して 1 万〜 10 万） が入るため熱化学的に進行 しない反応を起すことが可能であり，また反応の平衡を 一方的に生成系に傾かせることも可能となる。無声放電

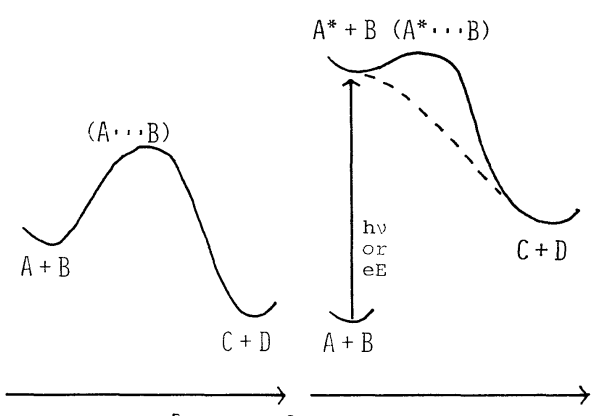

Reaction Coordinate

(a)

(b)

図 1 熱化学反応(a)と光括よびプラズマ化学反応(b) のちがい。（点線はイオンー分子反応） 


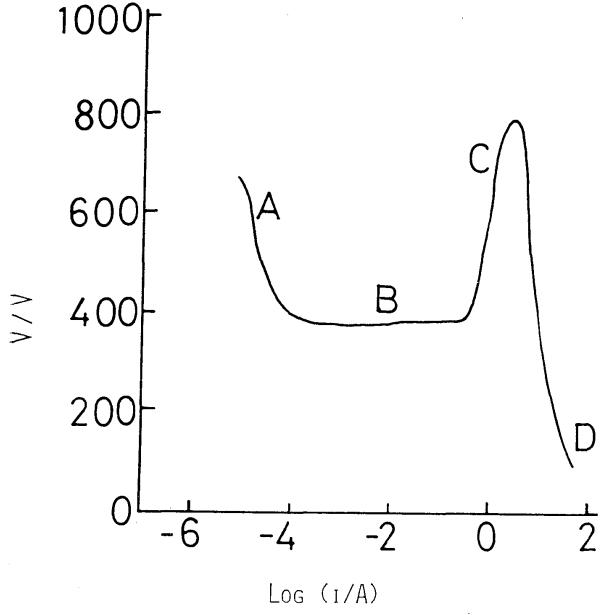

図 2 直流放電の場合の典型的な電圧-電流曲線 (数 Torr).

による $\mathrm{O}_{2}$ から $\mathrm{O}_{3}$ の生成などは典型的な例で，面白いと ころでは $\mathrm{N}_{2}-\mathrm{H}_{2}$ プラズマでは $\mathrm{NH}_{3}$ の生成量が平衡定数 から予測されるよりかなり大きくなるといら報告もあ る。第二にこれらの反応の多くは活性化エネルギーが低 いといらことである。たとえばイオン分子反応ではほと んどの場合活性エネルギーは○で，拡散支配の反応とな る。

さてこれらのうちでプラズマ化学反応の特徽は何であ ろらか。第一はプラズマ化学反応ではイオン（脑よび電 子）が必ず関与してくることでありそれらは電場により 加速され高い運動エネルギーを持つ。このことはプラズ マ中（特に低圧下で）では軽い粒子（電子）と重い粒子 （イオン）とのエネルギーが大幅に異なる（通常電子温 度とガス温度で表わされる）ことを意味し，この性質を 利用すると（これが工学的に最も重要な点であるが）熱 的（量的）な温度と反応を行なわせる上での質的な温度 を独立に容易に制御できる。さらに重要な点は，固体サ ンプルをプラズマ処理するとき，気体側と同様にサンプ ル温度も誘導加熱等の方法で広範囲に制御できることで 女る。

\section{3. プラズマの種類とその特徵}

\section{3-1 プラズマの種類}

プラズマは主に放電により発生させられる。図 2 に示 寸数 Torr の減圧下，直流放電を行なった場合の良く知 られた電流と電圧の関係を示す。 $\mathrm{B}$ の部分は電流が変っ ても電圧は変化しない。この部分をグロ一放電領域と称 し，Dで示す電流が増加して電圧が急激に下った状態を アーク放電領域と称する。定常的に発生しているプラズ マはこの二者に大別される。図３に圧力に対するガス温

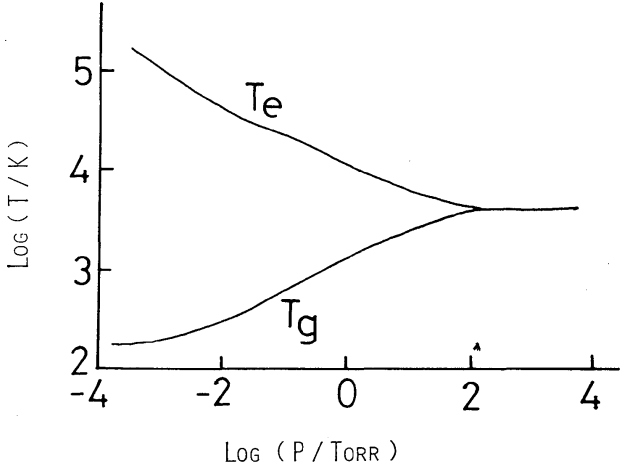

図 3 電子温度 $\left(T_{e}\right)$, ガス温度 $\left(T_{g}\right)$ と圧力の関係

度と電子温度との関係を示す。圧力の高いときは両者は 一致（つまり電子とガスとは熱的に平衡にありガス温度 は高いので「熱プラズマ」と呼ばれる）し，圧力が下る につれてガス温度は低くなり，反対に電子温度は高くな る。この領域では電子とガスの温度は異なる（平衡にな い）ので「非平衡プラズマ」またはガス温度が低いので 「低温プラズマ」と呼ばれる。一般にアーク放電は熱プ ラズマとして，グロ一放電は低温プラズマとして利用さ れる場合が多い。この二者の他に無声放電, コロナ放電 があるがこれはパルス状の放電に対して名づけられてい る。これはパルス状であるがゆえに高圧下でもガス温度 の低いプラズマを作ることができるので最近では「高圧 低温プラズマ」1)とも言われる。この他衝撃波によって もプラズマ状態を作ることが可能で女るし，日常親しん でいる高温の炎もプラズマの一種であるが本論をはずれ るので詳述はさける。

\section{3-2 プラズマ発生装置}

プラズマ発生装置にはいくつかの分類法がある。電極 の設置法で分けると，電極を系内に置く方法と，系外に 設置する無電極方式とがある。前者は直流放電に多く用 いられ薄膜形成にはサンプル自身が電極となる。後者は 高周波放電やマイクロ波放電など交流法に用いられるも ので反応系内にはプラズマガスとサンプルのみが置かれ るので不必要な污染がないという特徵をもつ。次に放電 を行う電源から分類すると，直流と交流放 電（低周 波 $(3 \mathrm{kHz}, 400 \mathrm{kHz})$ ，高周波 $(13.56 \mathrm{MHz})$ ，マイクロ波 $(2.45 \mathrm{GHz}))$ ，またこの両者を適当に組み合わせる方式 も考えられる。マイクロ波はレンズを用いて集光するこ ともできるので，無電極で局部的なプラズマ処理も可能 である。常圧で行なら熱プラズマの発生にはプラズマト 一チが良く用いられる。それらは移送式（陽極を用いる 方式）と非移送式（外部に陽極を用いない）に分類され る ${ }^{28)}$ 。前者は主に閉じた容器内で用いられ，後者はプラ ズマスプレーに代表されるようにオープンで用いるのに 


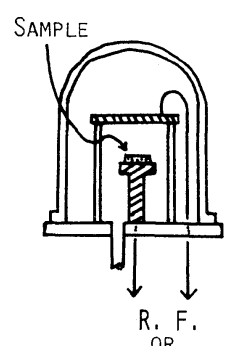

D. ${ }^{O R}$ C.

(a)

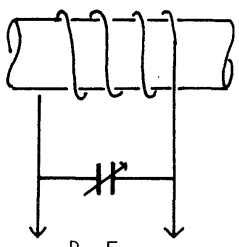

R. F.

(b)

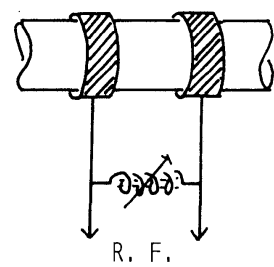

(c)

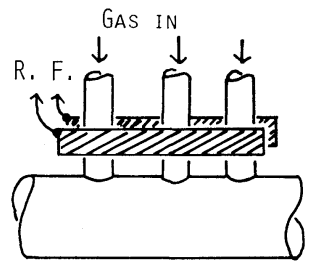

(d)

図 4 高周波放電プラズマ発生装置のいろいろ。(a)ベルジャ一型，(b)誘導結合方式， $(c, d)^{27)}$ 容量結合方式

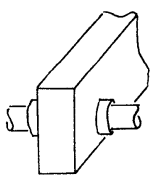

(a)

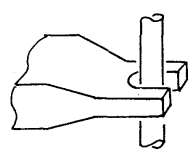

(b)

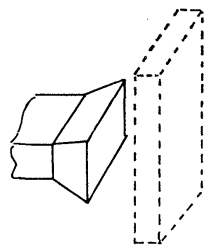

(c)
図 5 マイクロ波放電プラズマ発生装置のいろいろ。

(a)遵波管方式，(b)導波管方式(オープンエンド), (c)放射器方式

便利である。これらの他にレーザーを用いてプラズマを 発生する装置もある ${ }^{33)}$ 。

\section{4. プラズマを用いた薄膜形成技術}

本論に入る前に従来からある薄膜形成技術について簡 単に触れてみる 真空蒸着法に代表される PVD (Physical Vapor Deposition)から発展してきた。PVDには単純な蒸着法の他に 直流電圧をかけるイオンプレーティング，加速したイオ ンをターゲットに打ち込み，膜形成物質を気化するスパ ッタリング，さらに進んで真空蒸着とプラズマ励起を併 用した反応性蒸着法など種々の方式がある。現在「薄 膜」と言われるものの多くはこのPVD 法により形成さ れている。一方気相に沶いて化学反応を起し，これを 目的とする基板上へ析出させる方法を CVD (Chemical Vapor Deposition) といい，始めは常圧で行なわれてい たが後に PVD の技術と融合して減圧または真空下で行 なわれるようになってきた。たと党ば $\mathrm{SiH}_{4} \rightarrow \mathrm{Si} ， \mathrm{TaCl}_{5}$ $+\mathrm{NbCl}_{5} \rightarrow \mathrm{Ta}-\mathrm{Nb}, \mathrm{TiCl}_{4}+\mathrm{C}_{6} \mathrm{H}_{5}-\mathrm{CH}_{3} \rightarrow \mathrm{TiC}_{\text {。 }} \mathrm{CVD}$ は PVDに比べ多様的で応用分野も広い。PVD の場合プラ ズマは単に Assistant であるのに対し，プラズマがその 本来の特徴を発揮するのは主にこのCVD においてであ ろう。以下プラズマを用いるより一般的な成膜技術につ いて具体的な例をあげて示すことにする。

\section{4-1 低温プラズマによる薄膜形成}

4-1-1 半導体素子上での絶縁膜の形成（酸化抢よび 窒化) ${ }^{29), 311}$

$\mathrm{SiO}_{2}$ はシリコン素子における絶縁膜の最も代表的なる のであるしその後登場した $\mathrm{Si}_{3} \mathrm{~N}_{4}$ は絶縁性，耐酸化性， 耐熱性，アルカリイオンブロックなど $\mathrm{SiO}_{2}$ に代る絶縁 膜として実用化されている。従来これらの絶縁膜は，通 常の CVD, 高温での化学的酸化または窒化などで形成さ れてきた。しかしながら不純物ドーピングを主プロセス に含む半導体プロセス中ではこれら高温処理は致命的な 欠点である。従来 $900^{\circ} \mathrm{C} て ゙$ 行なわれてきた $\mathrm{Si}_{8} \mathrm{~N}_{4}$ 膜形成 に対し $\mathrm{SiH}_{4}+\mathrm{N}_{2}$ プラズマ中で行なう $\mathrm{CVD}$ では基板温 度 $300^{\circ} \mathrm{C}$ で高信頼性の $\mathrm{Si}_{8} \mathrm{~N}_{4}$ 膜（この膜は $\mathrm{Si}_{\mathrm{x}} \mathrm{N}_{\mathrm{y}} \mathrm{H}_{\mathrm{z}}$ の組 成を持つ）を作ることができる。またこれより高温では あるがグロ一放電を用いた $\mathrm{O}_{2}$ プラズマによる直接酸化， $\mathrm{N}_{2}$ または $\mathrm{N}_{2}+\mathrm{H}_{2}$ プラズマによる直接窒化も行なわれて いる2。プラズマ酸化は最近になって高速素子に用いら れている GaAs の絶縁膜形成に和いて特に重要である。 つまりAs の酸化物の蒸気圧が高いので高温処理は不可 能で，この場合低温で行な党るプラズマ酸化が不可欠な 手段となっている。

\section{4-1-2 アモルファスシリコン膜 ${ }^{29}$}

現在太陽光発電の目玉商品であり電卓などにも積極的 に取り入れられているアモルファスシリコン膜は $\mathrm{SiH}_{4}$ 系のプラズマCVDにより生成されている。この膜は「ア モルファス状態のシリコン」ではなく格子中に $\mathrm{Si}-\mathrm{H}$ 結 合を多く含むアモルファス状態の「水素化ヶイ素」とい った方が正しく，従来のシリコ、ン太陽電池より安価で効 率が良い。このアモルファス膜はプラズマを用いて始め て合成できたもので析出機構なぞにはまだ不明の点も多 いが，プラズマ化学反応の特徵を十分発揮したものとい 光る。

4-1-3 複合薄膜形成および不純物ドーピング 材料の特性が複合化により飛躍的に向上することは良 く知られている。シリコンに称いて従来の純粋な $\mathrm{Si}$, 
$\mathrm{SiO}_{2}, \mathrm{Si}_{3} \mathrm{~N}_{4}$ から $\mathrm{SiH}_{\mathrm{x}}, \mathrm{Si}_{\mathrm{x}} \mathrm{N}_{\mathrm{y}} \mathrm{H}_{\mathrm{z}}$ などの複合膜が高い性 能をもつことがわかっで ${ }^{29)}$, 複合膜形成の容易なプラズ マCVDの利用は増々活発となっている。一方a-Si 太陽 電池の作成には，同時に $\mathrm{B}_{2} \mathrm{H}_{6}$ などを微量混合し，シリ コン析出と同時に微量の不純物ドーピングを行なう技術 もある。このようにプラズマCVDによる複合膜の形成 は上記半導体関係だけでなく， $\mathrm{TiC}, \mathrm{TiN}, \mathrm{Si}_{3} \mathrm{~N}_{4}, \mathrm{SiC} な$ ぞの超硬質コーティングに和いても同時または交互の膜 形成に利用されている。この分野はその実用性からみて 今後各方面で利用されるようになるであろう。

4-1-4 プラズマ重合膜27),29)

炭化水素やケイ化水素などはプラズマ中に和かれると その高エネルギーのために分解し，種々のラジカルを生 成する。これらはプラズマから出れば当然再結合する。 最も簡単な例をあげれば $\mathrm{CH}_{4}$ や $\mathrm{C}_{2} \mathrm{H}_{4}$ プラズマでは, プ ラズマから少し離れた所にポリエチレン膜が器壁に析出 する。ポリエチレンの他にシリコン系3， テフロン系4) の重合膜形成も試みられている。応用面としてはレンズ のコーティング，逆浸透膜，選択性気体透過膜，高分子 被覆電極などがある。半導体関係ではレジスト膜 ${ }^{5)}$ の形 成がある。たと恼キャリアーに不活性ガスを用いモノ マーとしてメタクリル酸メチルを用いるとポリメチルタ アクリレート類似膜形成ができる。（メタクリル酸メチ ルはプラズマ開始重合6)（プラズマを開発剂として液体 中で重合を行5）に用いられて和り分子量3000万にも達 する超高分子が合成できる。むたスチレンなどとの共重 合も試みられている。

従来溶液系で行なわれてきた重合膜の多くが今後プラ ズマ法で 1 プロセスで行なわれるようになるのもそう遠 くない未来のことであろう。

\section{4-1-5 グロ一放電による金属の直接窒化，炭化}

従来直流放電で行なわれていた金属のイオン窒化，イ オン浸炭を, 交流プラズマを用い無電極方式で直接窒化 または炭化を行な沶らとするものである。Ti の窒化を 例にとると，高周波プラズマを用いた場合，誘導コイル 中にサンプルを置くと，約 $900^{\circ} \mathrm{C}$ ま誘導加熱され，プ ラズマにより励起した窒素分子，窒素分子イオンなどが 窒化を促進し，約 1 時間の窒化で厚さ数 $\mu \mathrm{m}$ ，表面硬度 $2000 \mathrm{kgmm}^{-2}$ の TiN の膜が得られる ${ }^{7)} \mathrm{Zr}$ の場合は膜厚 はTi より薄いが超伝導性を示す化学量論組成に近い $\mathrm{Zr}$ $\mathrm{N}_{1-\mathrm{x}}$ が得られている8 の窒化物 $\left(\mathrm{Fe}_{4} \mathrm{~N}, \mathrm{Fe}_{3} \mathrm{~N}\right)$ も容易にでき，硬度はバルクの 鉄の 4 倍 $\left(800 \sim 1000 \mathrm{kgmm}^{-2}\right)$ に達している ${ }^{9), 10) 。 ~}$

4-1-6 ダイヤモンド状薄膜

良く知られているよ5にダイヤモンドは熱力学的には 超高圧 $\left(10^{4} \sim 10^{5}\right.$ 気圧以上) で安定で，黒鉛をダイヤモン ドに変えるには触媒を用いても $2000^{\circ} \mathrm{C} ， 70000$ 気圧が必
要とされている。一方ダイヤモンドは高絶縁性でかつ熱 伝導率が非常に大きい数少ない物質であり, 集積化の進 む半導体素子の放熱材として注目されている。もしダイ ヤモンド薄膜が作成可能となればまさに革命的である。 ダイヤモンド薄膜の形成 ${ }^{11), 12)}$ は CVD, 高周波やマイク

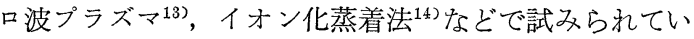
る。炭素源としてはメタン, アセチレンなどが用いられ る。現在までのところ結晶状のものについては数 $\mu \mathrm{m}$ 径 のものが報告されているが，これらの微粒子中には水素 がかなり含まれており熱伝導性については疑問が残る。 一方膜状のもの多得られて拈りこれは水素含有率も少な く13), 今後の発展が期待される。もし高品位のダイヤモ ンドの作成が可能となれば，プラズマを用いればマイル ドな条件下で「極限状態」26)を再現できることの確かな 証明ともなる。

\section{4-1-7 フッ化黒鉛薄膜 15}

フッ化黒鉛はー $(-\mathrm{CF})$ - $\mathrm{n}$ たは $-\left(-\mathrm{C}_{2} \mathrm{~F}\right)-\mathrm{n} て ゙$ 表わされる 高分子の炭素のフッ化物で，我国で開発された代表的な 無機材料である。この物質はテフロン以上に潤滑性が良 く，撥水性も良い。フッ化黒鉛は現在代表的な $3 \mathrm{~V}$ 電池 であるリチウム電池の陽極材料として商品化されてい る。フッ化黒鉛は400〜 $500^{\circ} \mathrm{C} て ゙$ 黒鉛をフッ素と反応させ ることにより生成するが，これを $\mathrm{SF}_{6} ， \mathrm{CF}_{4}$ などの反応 性の低いガス中でグロ一放電により黑鉛を処理すること により常温で作ることができる。

\section{4-1-8 プラズマによる表面処理}

これは膜形成ではないが，薄膜形成のプロセスの一つ として利用される可能性があるので取り上げた。黒鉛や プラスチック表面をプラズマ処理すると荒される。たと えば黒鉛を減圧下アルゴンプラズマ処理すると，あらか じめ存在する末端の $=\mathrm{O},-\mathrm{COOH},-\mathrm{OH}$ 基などは除去さ れる。逆にこれを $\mathrm{O}_{2}$ プラズマ処理すると活性なーCOOH やー $\mathrm{OH}$ 基を導入できる ${ }^{16)}$ 。またアルゴンプラズマ処理 したものにアルキルアミンを接触させるとアミノ基など 各種の官能基を導入でき，化学修飾電極に利用され ${ }^{17}$, イオンセンサー，酵素センサー，然料電池など多方面に 応用されている。プラスチックでは，物によっては10秒 程度の短時間の処理で, 単純なエッチング, 表面の架橋 反応，化学修飾，バルクー表面重合などを行ならことが できる。これらの処理による表面の改質, 塗装膜の密着 性の強化などにとどまらず，プラスチック上への直接化 学めっきが可能になり，パターンニングを施せば1回の プロセスでプリント板の化学めっきも可能になるであろ 5 。

\section{4-2 高圧低温プラズマの利用 ${ }^{1)}$}

低温プラズマは上記のように減圧下で作られる。一方 無声放電またはコロナ放電はパルス状の放電であるため 


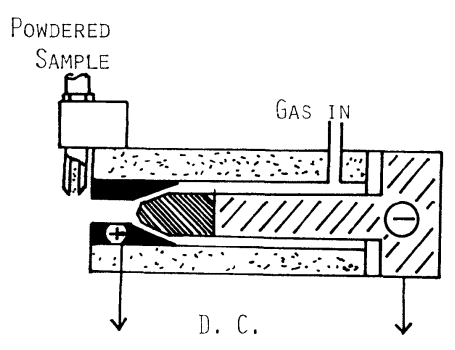

(a)

常圧または加圧状態でカス温度の低いプラズマを作るこ とができる。この放電では高価で取り扱いに経験の必要 な真空系が不要であり, かつ励起種の濃度も高いので実 用上のメリットが大きい。前節で述べたプラスチックの 表面処理などはわざわざ低圧で行なわなくても，この方 式を用いれば試料温度を下げたままで容易に処理でき $ろ^{18)}$ 。この放電の膜形成技術への応用研究はまだ少ない が, 常圧, 低温, 高濃度の特徵を生かし今後の発展が期 待される。

\section{4-3 熱プラズマの利用}

熱プラズマは低温プラズマと異なりガス（炎）自身が 高温であるため目的とする試料は融解状態となることが 多く, 反応速度も大さいので薄膜というよりはむしろ厚 膜形成に適している。この手法による耐熱性膜や超硬質 膜の形成技術は現在急速に進んできて执り応用分野も広 w。

\section{4-3-1 プラズマスプレー法19)}

現在熱プラズマによる膜形成はこの方法が最もポピュ ラーなるのである。一般的な方法は該当する物質の微粒 子またはロッドをプラズマトーチ内に導入し, トーチ内 で融解または気化させたものをスプレー溶射する方法で ある。図6に代表的な導入方法を模式的に示す。この場 合炎は熱ピンチ効果を利用して超音速のジェットとなっ

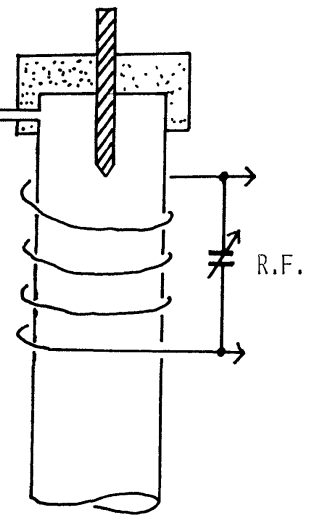

図 6

高温プラズマ発生装置, (a)直 流アークプラズマ（非移送 式), (b) 高周波誘導プラズマ （いずれもスタートは高圧高 周波により行なわれる。bの 上部の電極はスタート用に用 いられる。)

\section{(b)}

て吹き出す。（ほとんどの物質はこの炎の中では溶融状 態にある。）高融点物質, 断熱材, 超硬物質のライニッ グ，純金属や合金の薄膜形成など多方面に利用されてい る。セラミックス化の進む自動車エンジンのピストンヘ ッド, シリンダー内壁, ヘッド, ターボチャージャーハ ウジングなどにも用いられているし, 新しい所では最近 注目を集めている光透過性（透明）七ラミックスの表面 コーティングなどもこの方法により可能である。

通常プラズマスプレーはアルゴンのような不活性ガス をキャリアーとして空気中で行なわれるが，酸素を極端 に嫌 5物質等は密閉チャンバー内で行な5。さらに最近 では，減圧下ではプラズマトーチが大きく広がることを 利用して広い面積を均一に溶着の可能な減圧プラズマス プレー法 (LPPS), さらに高真空下で純金属等を高速で 溶射できる真空プラズマスプレーを用いれば半導体レベ ルの高品位の薄膜を高速で作ることも可能である。表 1 に現在市販されている代表的なスプレー材料のリストを 載せておく。

\section{4-3-2 高温安定相の析出 ${ }^{20)}$}

立方晶 $\mathrm{BN}$, 立方晶 $\mathrm{MoC}$, 立方晶 $\mathrm{WC}$, 立方晶 $\mathrm{TaN}$, 六方晶 $\mathrm{MoB}_{2}$ などは高温安定相であり，高温で合成でき ても冷却速度が遅いと他の結晶系へ転移してしまう。こ のため従来はSplat Cooling や溶融スズ中に括として急

表 1 プラズマスプレー用粉末

\begin{tabular}{|c|c|}
\hline $\begin{array}{ll}\text { 金属 } \\
\text { 合 金 }\end{array}$ & $\begin{array}{l}\mathrm{Cu}, \mathrm{Al}, \mathrm{W}, \mathrm{Ta}, \mathrm{Mo} \\
\text { Stainless steel, N1-Cr, N1-Cr-Mo, Cu-N1-In, Co-Mo-Cr, N1-Al }\end{array}$ \\
\hline $\begin{array}{l}\text { 炭化 物 } \\
\text { ケイ化物 } \\
\text { ホウ化物 }\end{array}$ & $\begin{array}{l}\mathrm{WC}, \mathrm{Co}_{-}-\mathrm{WC}, \mathrm{N}_{1}-\mathrm{C}, \mathrm{CrC}, \mathrm{S}_{1} \mathrm{C} \\
\mathrm{S}_{1}-\mathrm{Al} \\
\mathrm{BN}, \mathrm{S}_{1_{3} \mathrm{~N}_{4}}\end{array}$ \\
\hline 酸 化 物 & $\begin{array}{l}\mathrm{TlO}_{2}, \mathrm{Al}_{2} \mathrm{O}_{3}, \mathrm{Cr}_{2} \mathrm{O}_{3} \\
\mathrm{ZrO}_{2}-\mathrm{CaO}, \quad \mathrm{ZrO}_{2}-\mathrm{MgO}, \quad \mathrm{ZrO}_{2}-\mathrm{Y}_{2} \mathrm{O}_{3}, \mathrm{Al}_{2} \mathrm{O}_{3}-\mathrm{T}_{1} \mathrm{O}_{2},\end{array}$ \\
\hline その 他 & $\begin{array}{l}\text { Aluminum bronze+Polyester } \\
\mathrm{S}_{1}-\mathrm{Al}+\text { Polyester }\end{array}$ \\
\hline
\end{tabular}


冷する方法がとられてきた。一方上記のスプレーと同様 な方法によりトーチ内で高温相になった粉末を冷気（こ れら粒子は音速の 2 倍以上の速さで吹き出す）または冷 金属板上に吹き着壮急冷することができ，高温安定相を 得ることがでさる。たとえば六方晶 $\mathrm{MoC}$ の粉末をプラ ズマトーチ内に導き急冷することにより, 高温のトーチ 内で立方晶となった $\mathrm{MoC}$ をのまま得ることができ $ろ^{21)}$ 。このときの冷却速度は $10^{5} \mathrm{deg} \cdot \mathrm{s}^{-1}$ と見積られてい る。したがってプラズマスプレーはこのような高温安定 相を析出させるのにそのまま利用できる。

その他の利用法としては, 高融点物質の微粒子がプラ ズマトーチ内で融解することから，これら微粒子の表面 を平滑（球形）にすることもできる。

\section{4-4 減圧プラズマの利用}

これまで両極端の低温プラズマと熱プラズマについて 述べてきた。始めに概説したようにプラズマは外部から の制御が容易で，温度についても高低だけでなく，圧力 を適当に選べば中間の温度も容易に再現ぎきる。4-1-5 で述べたグロー放電中で Ti の窒化を行な5（試料温度 約 $\left.900^{\circ} \mathrm{C}\right)$ のに比べ, 減圧下でプラズマトーチを用いて窒 化を行えば(約100Torr, 試料温度 $1200^{\circ} \mathrm{C}$ ) 窒化速度は前 者に比べ約 100 倍も大きくなり，かつ超伝導性を示すよ 万な化学量論組成に近い $\mathrm{TiN}_{1-\mathrm{x}}$ が得られる ${ }^{22)}$ 。この減 压プラズマジェットは試料を $1000^{\circ} \mathrm{C} \sim 2500^{\circ} \mathrm{C}$ 範囲で自 由に調節でさるので，遷移金属の炭化，窒化，ホウ化な ぞを，試料を溶かさないでかつすみやかに行なうことが できる。

\section{4-5 膜形成の制御 ${ }^{30}$}

先に述べたようにプラズマ自身，または試料温度など は, 放電の種類, 圧力, 電力（電流または電圧）によっ て容易に制御できる。しかしながら生成する膜について 再現性を得ることは意外にむずかしい。このためには放 電中の成膜速度, 温度, プラズマの状態などを適時チェ ックする必要がある。膜厚については干渉などを利用し た光学的方法, 電気抵抗によるもの, マイクロバランス などがあるが，プラズマ自身が発光していること，伝導 性の気体であること，プラズマ内にかなりの電位勾配が 存在すること，電磁気的ノイズが大きいことなど，測定 をむずかしくしている点が多い。温度测定についても同 じことが障害となる。一方プラズマ自身については反応 機構の解明のための各種のプラズマ診断法（発光スペク トル，マススペクトル，探針法など）があるが膜成長の 制御に使うことはあまり望めない。また生成膜をin situ かつ非破壊で調べることのできるオージェ分光, XMA， IMA などもあるが，高価であること，本稿で主として 取りあげた比較的高圧で行なうようなプラズマプロセス に拈いてはこれらを膜形成の制御に用いることは不適当
である。したがってプラズマ成膜技術を手軽に利用する ためにはそれぞれの場合に応じた膜生長の制御法を開発 することが一つのポイントとなると思われる。

\section{5. おわりに}

以上化学に携わる者の立場に立って各種プラズマの多 方面への応用およびその可能性について雑駁に述べてき た。これらからプラズマが意外と身近なもので取り扱い 易いものであることを感じ取っていただければ幸であ る。またここで述べたよ5な「プラズマ化学」の分野は まだ研究者が少ないのでその裾野が少しでも広がること に役立つことを望むものでまる。本稿では現在先端技術 として脚光をあびている半導体産業におけるプラズマプ ロセスについての詳述は避けた。これらの技術について は別途その方面の専門家による解説が企画されることを お願いする次第である。

最後に本総説を書くにあたり多くの御助言および資料 の提供をいただいた上智大学理工学部工業 物 理 学 講座 （岡崎幸子教授）小駒益弘博士，高周波およびマイクロ 波プラズマ技術の資料を提供していただいた日本高周波 㧣速水英治氏，プラズマスプレー技術について資料を提 供していただいた第一メテコ秼，表面処理技術について 御助言をいただいた田代電化工業侏塩田裕治氏に深く感 謝の意を表します。

\section{文献}

1）岡崎幸子；日本工業新聞，昭和59年 1 月 11 日号

2) O. Matsumoto and Y. Yatsuda; Proc. 5th Int. Symp. Plasma Chem., p. 382, Edinburgh (1981)

3) 原口俊秀, 井手俊輔, 狩猪重雄, 金崎健児; 電気化 学協会第51回大会講演要旨集 p. 274（1984）

4) 寺田一郎, 梶山千里, 高柳素夫, 原口俊秀; 電気化 学協会第51回大会講演要旨集 p. 275 (1984)

5) S. Morita, J. Tamano, S. Hattori, and M. Ieda ;

J. Appl. Phys., 51, 3938 (1980)

6）長田義仁；応用物理, 50, 1205 (1981)

7) M. Konuma and O. Matsumoto; J. Less-Common Metals, 52, 145 (1977)

8) M. Konuma and O. Matsumoto; ibid., 55, 97 (19 77)

9) M. Konuma, Y. Kanzaki, and O. Matsumoto; Denki Kagaku, 47, 597 (1979)

10) Y. Taniguchi and K. Akashi ; ibid., 46, 560 (1978)

11）瀬高信雄；真空, 26, 7 (1983)

12）松本精一郎；日本結晶学会誌，25，212（1983）

13) O. Matsumoto, H. Toshima, and Y. Kanzaki ; Denki Kagaku 52, 128 (1984)

14）鄭海濤, 毛利敏男, 難波義捷; 真空, 26, 622（19 83)

15）小駒益弘，森脇隆夫，岡崎幸子; 電気化学協会'82 秋季大会講演要旨集 p. 183 (1982)

16) N. Oyama, A.P.Brown, and F.C. Anson ; J. Electroanal. Chem., 87, 435 (1978) 
17) R. Nowak, F.A. Schultz, M. Umana, H. Abruna, and R.W. Murray; ibid., 94, 219 (1978)

18）角田光雄, 小石真純；工業材料，29，105（1981）

19) Proc. 7th Int. Conf. Vac. Metall. Coat. 1982 Paper Metall. Coat., Japan（1982）中に多くの論文がある。

20）松本修；金表誌，33，635（1982）

21) O. Matsumoto and Y. Mitarai ; Denki Kagaku, 43, 145 (1976)

22）速気英治，神㥓愷，松本修; 電気化学協会第48回大 会講演要旨集 p.71（1981）

参考書抢よび解説

23) Proc. Int. Symp. Plasma Chem., IUPAC, 1st (19 73) -6 th (1983)

24）松本修；セラミックス, 11, 1093 (1976)
25）明石和夫, 吉田豊信; 電気化学, 44, 140 (1976)

26）極限の化学,「化学々工業」36巻, 11 号 (1983)

27）穂積㤵一郎編，「低温プラズマ化学」南江堂 (1976)

28）早川保昌，松本修；「プラズマ化学ととの応用」裳 華房 (1971)

29）「電子材料」編集部編，「超L S I 時代のプラズマ 化学」工業調查会 (1983)

30）麻蒔立男；「薄膜作成の基礎」日刊工業新聞社（19 77)

31）菅野卓雄編「半導体プラズマドライプロセス技術」 産業図書 (1980)

32) 電気学会編「電離気体論」電気学会 (1969)

33）玉河元編「放電」共立出版（1975） 